\title{
Kebebasan Hakim dalam Penjatuhan Pidana terhadap Pelaku Tindak Pidana Korupsi Bantuan Sosial Covid-19 Dikaitkan dengan Asas Keadilan dan Dasar Pemberatan Penyalahgunaan Kewenangan
}

\author{
Adinda Anisa Putri Noor Oetari*, Ade Mahmud \\ Prodi Ilmu Hukum, Fakultas Hukum, Universitas Islam Bandung, \\ Indonesia. \\ *adindaa513@gmail.com, ademahmud100@yahoo.com
}

\begin{abstract}
The increasing number of acts of corruption shows that there is still a lack of eradication of corruption. In the pandemic COVID-19, the Ministry of Social Affairs officials corrupt the COVID-19 social funds. On that case, the problems in this study are (1) How is the corruption of social funds in Putusan No.29/Pid-Sus-TPK/2021/PN Jkt. Pst related to the abuse of authority in Article 52 of the Criminal Code? (2) How is the implementation of judges' freedom in imposing criminal acts of corruption on social funds carried out by state officials associated with the principle of justice. The research was conducted with normative juridical approach based on an approach to the principles and legal rules related to Law Number 20 of 2001 concerning Amendments to Law Number 31 of 1999 concerning Eradication of Criminal Acts of Corruption, also research is carried out by library materials or secondary data in the form of books, journals, and regulations related to this research. The results is the criminal basis for the abuse of authority Article 52 can be carried out because the offenses in Article 52 of the Criminal Code have been fulfilled but the Judge didn't accommodate the Article so the punishment is disappointing. Judges in interpreting and considering the imposition of punishments didn't concern the elements of losses suffered by the community and the state. Instead, the judge used the public's disappointed response to this corruption as an excuse to reduce the victim's punishment and justice for the community was not achieved.
\end{abstract}

Keywords: Corruption Crime, Abuse of Authority, Principle of Justice

\begin{abstract}
Abstrak. Semakin banyak nya pejabat yang melakukan tindak pidana korupsi menunjukan masih kurang nya pemberantasan tindak pidana korupsi. Pada situasi COVID-19 pejabat kementerian sosial melakukan korupsi dana bantuan sosial COVID-19 yang ditujukan untuk membantu kehidupan masyarakat. Pada kasus tersebut maka permasalahan pada penelitian ini adalah (1) Bagaimana tindak pidana korupsi bantuan sosial COVID-19 putusan No.29/Pid-Sus-TPK/2021/PN Jkt. Pst dihubungkan dengan dasar pemberatan penyalahgunaan kewenangan Pasal 52 KUHP? (2) Bagaimana implementasi kebebasan hakim dalam penjatuhan pidana terhadap tindak pidana korupsi bantuan sosial COVID-19 yang dilakukan pejabat negara pada putusan No.29/Pid-Sus-TPK/2021/PN Jkt. Pst dihubungkan dengan asas keadilan. Penelitian dilakukan dengan pendekatan yuridis normatif dengan pendekatan terhadap asas-asas dan aturan-aturan hukum yang berhubungan dengan Undang - Undang Nomor Nomor 20 Tahun 2001 tentang Perubahan Atas Undang-Undang Nomor 31 Tahun 1999 tentang Pemberantasan Tindak Pidana Korupsi, penelitian hukum kepustakaan yang dilakukan dengan cara meneliti bahan-bahan pustaka atau data sekunder berupa buku, jurnal, dan peraturanperaturan yang berkaitan dengan penelitian ini. Hasil penelitian penggunaan dasar pemberat pidana penyalahgunaan kewenangan Pasal 52 Pada korupsi bantuan sosial dapat dilakukan sehingga hukuman dapat diperberat karena delik-delik pada Pasal 52 KUHP telah terpenuhi namun Hakim tidak mengakomodir Pasal tersebut sehingga hukum ringan dan memicu masyarakat kecewa. Hakim dalam menafsirkan dan mempertimbangkan hukuman tidak memperhatikan unsur kerugian yang diderita masyarakat dan negara. Hakim malah menjadikan respon kecewa masyarakat terhadap korupsi ini sebagai alasan meringankan hukuman sehingga keadilan bagi masyarakat tidak tercapai.
\end{abstract}

Kata Kunci: Tindak Pidana Korupsi, Penyalahgunaan Kewenangan, Asas Keadilan. 


\section{A. Pendahuluan}

Pada saat ini kejahatan kian meningkat dengan berbagai macam motif yang membuat seseorang berani melakukan apapun termasuk melakukan perbuatan melawan hukum, tidak hanya karena faktor perekonomian yang kurang, namun juga semakin marak nya perbuatan melawan hukum yang dilakukan oleh pihak-pihak pemangku jabatan seperti tindak pidana korupsi. Berbagai macam bentuk korupsi yang telah terjadi di Indonesia misalnya: korupsi pengadaan barang dan jasa, mark up anggaran, proyek fiktif, penyalahgunaan anggaran dan suap, bahkan bantuanbantuan sosial (Bansos) untuk rakyat miskin seperti jaring pengaman sosial dan bantuan untuk korban bencana alam pun tidak luput dari praktik korupsi.

Pelaku kejahatan korupsi yang sebagian besar adalah pejabat, menunjukkan bahwa kejahatan ini bukan termasuk kejahatan biasa (conventional crime/blue collar crime) melainkan sudah termasuk kategori white collar crime di sektor publik dan melibatkan pihak-pihak pemegang kekuasaan publik dan pejabat pemerintahan sehingga disebut dengan kejahatan jabatan (occupational crime). Sama hal nya dengan pelaku tindak pidana korupsi dana Bantuan Sosial COVID-19 yang merupakan seorang pejabat publik Kementerian Sosial JB pada Putusan No.29/Pid-Sus-TPK/2021/PN Jkt. PSt.

JB merupakan seorang Menteri Sosial mengelola 1,6 juta paket bansos COVID-19 untuk penanganan Bantuan Sosial Penanganan COVID-19 pada Kementerian Sosial tahun Anggaran 2020. Total paket sembako yang dibagikan kepada masyarakat sebanyak 22,7 juta paket dengan rincian 12 tahapan dan harga setiap paket sebesar Rp.300.000. Korupsi yang dilakukan nya adalah dengan modus meminta fee sebesar Rp.10.000 kepada korporasi-korporasi yang mendapatkan proyek pengadaan sembako untuk masyarakat sekitar Jakarta, Bogor, Depok, Tangerang dan Bekasi (JABODETABEK) melalui Kuasa Pengguna Anggaran (KPA) dan Pejabat Pembuat Komitmen (PPK) yang juga menjadi terdakwa dalam kasus ini.

Berdasarkan keterangan saksi bahwa JB menargetkan penerimaan sebesar Rp35.000.000.000 dari pengadaan paket bansos COVID-19 di Kementerian Sosial. Pada hasil putusan nya JB terbukti melakukan korupsi Bantuan Sosial COVID-19 sebesar Rp.32.482.0000.0000 dari 109 perusahaan penyedia bansos COVID-19. Suap diterima bersama dengan dua PPK di Kementerian Sosial, yaitu MJ dan AE. Selain itu, sumber uang berasal dari pengusaha HV sebanyak Rp.1,28 miliar dan AI sebanyak Rp.1,9 miliar. Sedangkan sebanyak Rp.29,2 miliar dari beberapa perusahaan penyedia barang sembako bansos Covid-19.

Pada Putusan Hakim No.29/Pid-Sus-TPK/2021/PN Jkt. Pst. JB dijatuhi vonis 12 tahun penjara, hukuman denda Rp500.000.000,00 dan pencabutan hak politik selama 4 tahun setelah menjalani masa pidana pokok. Selain pidana pokok, jaksa KPK menuntut JB dihukum membayar uang pengganti sebanyak Rp.14,5 miliar. Hukuman yang dijatuhkan kepada JB tersebut dinilai kurang memenuhi keadilan bagi masyarakat terutama yang menjadi korban meskipun hukum yang dijatuhkan tersebut sudah berdasarkan pada subjektivitas hakim dalam memutus putusan karena sepanjang keadaan meringankan tersebut masih ada, hakim tetap harus mempertimbangkannya namun perlu diperhatikan pula bahwa secara umum hukum memiliki tiga tujuan pokok, yakni Keadilan, Kepastian Hukum, dan Kemanfaatan. Undang-Undang No. 48 Tahun 2009 tentang Kekuasaan Kehakiman menyebutkan hakim wajib menggali, mengikuti, dan memahami nilai-nilai hukum dan rasa keadilan yang hidup di masyarakat selaras dengan perkataan Sudjipto Rahardjo bahwa seorang hakim harus mewakili suara rakyat yang diam yang tidak terwakili dan yang tida terdengar. Selain itu dalam dakwaan nya hakim tidak mengakomodir Pasal 52 Kitab Undang-Undang Hukum Pidana (KUHP) yang menyebutkan bahwa bilamana seorang pejabat karena melakukan perbuatan pidana melanggar suatu kewajiban khusus dari jabatannya, atau pada waktu melakukan perbuatan pidana memakai kekuasaan, kesempatan atau sarana yang diberikan kepadanya karena jabatannya, pidananya dapat ditambah sepertiga. Praktik korupsi bansos ini dilakukan saat JB berkedudukan sebagai pejabat publik Menteri Sosial dan sebagai pengawas serta penunjukan Komisi Pengguna Anggaran di Program Dana Bansos COVID-19. Merujuk hal tersebut sehingga JB dapat dikenai pemberatan pidan bahkana pidana maksimal karena tindak pidana korupsi merupakan pelanggaran hak-hak sosial dan hak-hak ekonomi masyarakat, sehingga dapat digolongkan sebagai kejahatan luar biasa (extra-ordinary crimes) sehingga pemberantasnnya pun harus 
dilakukan dengan cara yang luar biasa pula (extra-ordinary enforcement)

Berdasarkan latar belakang yang telah diuraikan, maka perumusan masalah dalam penelitian ini sebagai berikut: "Bagaimana tindak pidana korupsi bantuan sosial COVID-19 putusan No.29/Pid-Sus-TPK/2021/PN Jkt. Pst dihubungkan dengan dasar pemberatan penyalahgunaan kewenangan Pasal 52 KUHP?" "Bagaimana implementasi kebebasan hakim dalam penjatuhan pidana terhadap tindak pidana korupsi bantuan sosial COVID-19 yang dilakukan pejabat negara pada putusan No.29/Pid-Sus-TPK/2021/PN Jkt. Pst dihubungkan dengan asas keadilan?". Selanjutnya, tujuan dalam penelitian ini diuraikan dalam pokok-pokok sbb.

1. Untuk mengetahui tindak pidana korupsi bantuan sosial COVID-19 putusan No.29/PidSus-TPK/2021/PN Jkt. Pst dihubungkan dengan dasar pemberatan penyalahgunaan kewenangan.

2. Untuk mengetahui implementasi kebebasan hakim dalam penjatuhan pidana terhadap tindak pidana korupsi bantuan sosial COVID-19 yang dilakukan pejabat negara pada putusan No.29/Pid-Sus-TPK/2021/PN Jkt. Pst.

\section{B. Metodologi Penelitian}

Metode penelitian yang akan digunakan dalam penelitian ini adalah penelitian yuridis normatif. Metode penelitian yuridis normatif adalah penelitian hukum kepustakaan yang dilakukan dengan cara meneliti bahan-bahan pustaka atau data sekunder belaka baik berupa buku-buku, jurnal, dan peraturan-peraturan yang mempunyai korelasi terhadap pembahasan masalah, sehingga penulisan ini juga bersifat penulisan pustaka (library research). Secara yuridis penelitian didasarkan pada pendekatan terhadap asas-asas dan aturan-aturan hukum yang berhubungan dengan tindak pidana korupsi seperti Undang-Undang Nomor 20 Tahun 2001 tentang Perubahan Atas Undang-Undang Nomor 31 Tahun 1999 tentang Pemberantasan Tindak Pidana Korupsi. Penelitian ini dilakukan dengan mengkaji peraturan perundang-undangan yang berkaitan dengan pemidanaan tindak pidana korupsi dalam alasan pengurangan sanksi pidana pelaku tindak pidana korupsi bantuan sosial COVID-19. Penelitian ini akan dilakukan dengan cara menarik asas hukum, dimana dilakukan terhadap hukum positif baik secara tersirat maupun tersurat. Data-data yang sudah diperoleh tersebut selanjutnya akan dianalisis sehingga dapat memperoleh penjelasan yang sistematis mengenai permasalahan hukum dalam penelitian ini.

\section{Hasil Penelitian dan Pembahasan}

Tindak Pidana Korupsi Bantuan Sosial COVID-19 Putusan No.29/Pid-Sus-TPK/2021/PN Jkt. Pst Dihubungkan Dengan Dasar Pemberatan Penyalahgunaan Kewenangan Pasal 52 KUHP.

Hakim mendakwakan JB pada putusan No.29/Pid-Sus.TPK/2021/PN Jkt. Pst dengan pasal suap yaitu Pasal 12 huruf b Undang-Undang Nomor 31 Tahun 1999 sebagaimana telah diubah dengan Undang-Undang Nomor 20 tahun 2001 tentang Peberantasan Tindak Pidana Korupsi. Pada Pasal 12 huruf $b$ tersebut terdapat pula unsur pegawai negeri atau penyelenggara negara. JB pada saat melakukan tindak pidana korupsi menjabat sebagai Menteri Sosial Kabinet Indonesia Maju periode 2019-2024 sehingga terdakwa merupakan penyelenggara negara. Terpenuhinya unsur pegawai negeri maka seharunya terdakwa dapat dikenakan dasar pemberat penyalahgunaan kewenangan Pasal 52 KUHP. Suatu tindak pidana ntuk dapat diperberat berdasarkan Pasal 52 KUHP, perbuatan pelaku harus memenuhi syarat-syarat:

1. Pelaku tindak pidana harus pegawai negeri,

2. Pegawai negeri tersebut harus melanggar kewajiban yang istimewa atau khusus dan menggunakan kekuasaaan, kesempatan atau daya upaya (alat) yang diperoleh karena jabatannya.

Memperhatikan unsur serta syarat dapat digunakan nya Pasal 52 KUHP diatas, terdakwa JB pada tindak pidana korupsi Putusan No 29/Pid.Sus-TPK/2021/JKT. Pst jika dilakukan penguraian unsur-unsur tindak pidana pemberatan perbuatan pidana yang dilakukan oleh JB adalah sebagai berikut:

1. Unsur pegawai negeri. 
JB pada saat melakukan tindak pidana korupsi menjabat sebagai Menteri Sosial kabinet Indonesia Maju periode 2019-2024.

2. Unsur pegawai negeri melanggar kewajiban khusus dari jabatannya

Dalam suatu jabatan in casu jabatan publik yang dipangku oleh seorang pegawai negeri terdapat suatu kewajiban khusus di dalamnya. Suatu kewajiban khusus adalah suatu kewajiban yang berhubungan erat dengan tugas pekerjaan tertentu dari suatu jabatan. Pada sidang lanjutan di Pengadilan Negeri Jakarta Pusat terdakwa JB menyatakan bahwa sebelumnya ia menjabat sebagai Menteri Sosial Kabinet Indonesia Maju periode 20192024 dan tugas khusus sebagai Pengguna Anggaran lalu pada Program Pengadaan Bantuan Sosial COVID-19 ia berkedudukan sebagai Penunjuk Kuasa Pengguna Anggaran dan Pengawas pengelolaan dan pendistribusian bantuan sosial COVID-19.

3. Unsur Menggunakan kekuasaan, kesempatan, atau sarana yang diberikan kepadaanya karena jabatannya untuk melakukan tindak pidana.

JB melakukan tindak pidana korupsi suap dengan modus meminta fee cashback Rp10.000 dari setiap paket sembako yang berharga Rp300.000 kepada korporasikorporasi vendor yang menjadi pemasok sembako pada Program Pengadaan Bansos COVID-19 untuk masyarakat sekitar JABODETABEK. Tindak pidana korupsi yang dilakukan JB Bersama pejabat-pejabat lainnya tersebut dikategorikan sebagai tindak pidana suap oleh Hakim dengan terbukti secara sah telah menerima sejumlah uang Rp 32.482.0000.0000 dari 109 korporasi vendor Bantuan Sosial COVID-19.

Apabila Pasal 52 KUHP diakomodir pada tindak pidana korupsi putusan Putusan No.29/Pid-Sus-TPK/2021/PN Jkt. Pst ini, maka hukum pidana terhadap terdakwa JB dapat diperberat sepertiga yaitu menjadi pidana penjara selama 16 tahun. Selain Pasal 52 KUHP, pada Pasal 2 ataupun Pasal 3 Undang-Undang Nomor 20 Tahun 2001 tentang Perubahan Atas Undang-Undang Nomor 31 Tahun 1999 tentang Pemberantasan Tindak Pidana Korupsi terdapat pula pengaturan mengenai pegawai negeri yang melakukan tindak pidana korupsi dengan adanya unsur pemberatan pdiaan yaitu pidana penjara seumur hidup hingga hukum mati. Pasal 2 dan Pasal 3 Undang-Undang Nomor 20 Tahun 2001 tentang Perubahan Atas Undang-Undang Nomor 31 Tahun 1999 tentang Pemberantasan Tindak Pidana Korupsi tersebut dapat diakomodir jika tindak pidana korupsi ini memenuhi unsur penyalahgunaan wewenang dan adanya unsur kerugian keuangan negara. Unsur penyalahgunaan pada kasus tindak pidana korupsi ini sudah terpenuhi seperti yang sudah penulis uraikan diatas, sehingga Juliari $\mathrm{P}$ Batubara secara sah telah melakukan penyalahgunaan wewenang yang terdapat dua unsur. Pertama, unsur "menyalahgunakan kewenangan, kesempatan, atau sarana yang ada karena jabatan atau kedudukan" artinya menggunakan kewenangan, kesempatan, atau sarana yang melekat pada jabatan atau kedudukan yang dijabat atau diduduki untuk tujuan lain dari maksud diberikannya kewenangan, kesempatan, atau sarana tersebut. Kedua, unsur "menyalahgunakan kewenangan" dapat didefinisikan sebagai perbuatan yang dilakukan oleh orang yang sebenarnya berhak untuk melakukannya, tetapi dilakukan secara salah atau diarahkan pada hal yang salah dan bertentangan dengan hukum atau kebiasaa. Sedangkan unsur merugikan keuangan negara merupakan hal yang penting untuk diteliti pada kasus korupsi ini karena sangat beririsan dengan kerugian keuangan negara dan pengadaan barang dan jasa. Namun penyelidikan adanya indikasi kerugian keuangan negara bukanlah hal yang mudah. Dana bansos COVID-19 yang telah dianggarkan pemerintah pada tahun 2019 mencapai Rp6,8 triliun yang berasal dari APBN yang penggunaan nya diprioritaskan untuk penanganan Pandemi COVID-19 serta dampak yang ditimbulkannya berupa ancaman yang membahayakan perekonomian nasional dan/atau stabilitas sistem keuangan dengan pada belanja kesehatan, jaring pengaman sosial, dan pemulihan perekonomian negara sebagaimana yang diatur pada Keputusan Menteri Sosial Nomor 100/HUK/2020 tentang Perubahan Kedua Atas Keputusan Menteri Sosial Nomor 54/HUK/2020 tentang Pelaksanaan Bantuan Sosial Sembako dan Bantuan Sosial Tunai dalam Penanganan Dampak COVID-19. Untuk menemukan adanya unsur kerugian keuangan negara, KPK pun menunjuk BPK untuk menyelidikan unsur kerugian keuangan negara pada korupsi bansos ini namun tentu bukan hal yang meudah untuk untuk menentukan adanya indikasi 
kerugian keuangan negara dan pengadaan barang dan jasa karena program bansos ini melibatkan banyak pihak seperti korporasi-korporasi yang menjadi vendor penyedia sembako program bansos ini.

Untuk dapat diterapkan nya Pasal 2 ini yang memiliki pengaturan pidana mati apabila korupsi dilakukan dalam keadaan tertentu. Yang dimaksud dengan "keadaan tertentu" dalam ketentuan ini adalah keadaan yang dapat dijadikan alasan pemberatan pidana bagi pelaku tindak pidana korupsi, yaitu apabila tindak pidana tersebut dilakukan terhadap dana-dana yang diperuntukkan bagi penanggulangan keadaan bahaya, bencana alam nasional, penanggulangan akibat kerusuhan sosial yang meluas, penanggulangan krisis ekonomi dan moneter, dan pengulangan tindak pidana korupsi. Jika dikaitkan dengan kasus ini maka korupsi bansos ini dilakukan pada keadaan tertentu pada saat pandemi COVID-19 yang merupakan bencana non alam yang memberikan akibat yang lebih besar dibanding bencana alam, selain itu Presiden Joko Widodo secara resmi telah menetapkan COVID-19 sebagai bencana nasional melalui Keputusan Presiden Republik Indonesia Nomor 12 Tahun 2020 tentang Penetapan Bencana Non-Alam Penyebaran COVID-19 Sebagai Bencana Nasional dan Keputusan Presiden Nomor 11 Tahun 2020 tentang Penetapan Kedaruratan Kesehatan Masyarakat COVID-19 penyalahgunaan alokasi dana penanggulangan wabah COVID-19 dapat dikategorikan sebagai tindak pidana korupsi yang dilakukan dalam keadaan tertentu maka pelakunya dapat diancam dengan pidana mati. Maka apa dikaitkan dengan kasus korupsi dana bansos COVID-19 ini, unsur dilakukan dalam keadaan tertentu pada Pasal 2 Undang-Undang Pemberantasan Tindak Pidana Korupsi tersebut telah terpenuhi sehingga pada Juliari P Batubara terdapat kemungkinan untuk mendapatkan hukuman lebih barat bahkan hingga hukuman mati. Namun tentu hakim harus pula mempertimbangkan unsur meringankan dan juga syarat lain agar dapat dikenakan nya pasal tersebut yaitu unsur kerugian keuangan negara.

\section{Implementasi kebebasan hakim dalam penjatuhan pidana terhadap tindak pidana korupsi bantuan sosial COVID-19 yang dilakukan pejabat negara dihubungkan dengan asas keadilan putusan No.29/Pid-Sus-TPK/2021/PN Jkt. Pst}

Asas Kebebasan Hakim Pasal 24 ayat (1) UUD 1945 yang menentukan bahwa: "Kekuasaan kehakiman merupakan kekuasaan yang merdeka untuk menyelenggarakan peradilan guna menegakkan hukum dan keadilan". Kebebasan hakim tersebut dalam penerapannya harus dibatasi dengan nilai-nilai keadilan karena keadilan merupakan salah satu tujuan hukum disamping kepastian hukum dan kemanfaatan. Kebebasan hakim dalam melaksanakan wewenang yudisialnya tidak mutlak karena tugas hakim adalah untuk menegakkan hukum dan keadilan berdasarkan Pancasila dan UUD 1945 sehingga putusannya mencerminkan rasa keadilan rakyat Indonesia sesuai dengan dasar Pancasila, bukan keadilan subyektif menurut pengertian atau kehendak hakim semata untuk tercapainya keadilan formal prosedural. Namun, dalam pelaksanaannya hakim akan kesulitan untuk mengakomodir ketiga tujuan hukum diatas, sehingga seorang hakim harus mempertimbangkan ke mana akan mengarahkan putusan, apaka lebih dekat dengan kepastian atau keadilan, disinilah prinsip kemandirian hakim diuji dalam menciptakan keadilan. Penemuan hukum oleh hakim menurut Sudikno Mertokusumo merupakan suatu proses pembentukan hukum oleh hakim atau petugas-petugas hukum lainnya yang diberi tugas menerapkan hukum terhadap peristiwa-peristiwa hukum yang konkret. Meskipun di Indonesia merupakan negara hukum yang memiliki tradisi civil law system, pendapat Sudikno Mertokusumo dan Eddy O.S diatas perlu diadaptasi dalam penemuan hukum demi terwujudnya putusan yang berkeadilan substantive karena sejalan dengan gagasan penegakan hukum progresif yang dapat menjadi alternaif bagi penegak hukum untuk menghadirkan keadilan substantif dengan lengkah progresif dan menerobos kekakuan hukum tertulis rule breaking.

Berbicara mengenai keadilan bagi kepentingan umum atau sosio legal cultural, Hakim Pengadilan Negeri Jakarta Pusat dalam mempertimbangkan Putusan No 29/Pid.SusTPK/2021/JKT hasil penelitian menunjukan bahwa putusan tersebut masih kurang memperhatikan dan memenuhi keadilan yang dicita-citakan masyarakat terutama bagi yang terkena dampak langsung dari perbuatan korupsi dana bansos COVID-19 yang dilakukan JB. 
Hakim dalam melakukan penemuan hukum dan mempertimbangkan putusan ini cenderung hanya berfokus pada perbuatan melawan hukum yang dilakukan terdakwa JB dan terhadap pemidanaan nya saja, tidak dengan mempertimbangkan pula akibat dari perbuatan pidana nya tersebut bagi masyarakat dan negara yang menderita kerugian negara. Hal tersebut dapat dilihat bahwa pada hal-hal yang menjadi pertimbangan hakim dalam menentukan putusan pidana pada hal-hal yang meringankan salah satunya "Bahwa terdakwa telah cukup menderita karena menerima cacian dari masyarakat padahal belum tentu terdakwa bersalah." Respon cacian masyarakat berdasarkan asas keadilan yang mengatakan bahwa putusan yang berkeadilan adalah yang menjawab kehendak masyarakat, maka respon cacian masyarakat terhadap terdakwa merupakan respon yang wajar menunjukan kekecewaan terhadap pemerintah yang melakukan korupsi dana bansos yang peruntukannya untuk membantu kelangsungan masyarakat di tengan COVID-19 ini, selain itu respon masyarakt tersebut merupakan sikap anti korupsi yang mana hal tersebut adalah hal yang tepat untuk membantu pengurangan tidak pidana korupsi di Indonesia. Hakim dalam menjatuhkan Putusan No.29/Pid-Sus/TPK/2021/PN Jkt. Pst. belum memenuhi asas keadilan bagi masyarakat terutama yang menjadi korban dana bansos COVID-19 ini karena dalam pertimbangan nya Hakim tidak mengakomodir unsur kerugian yang diderita masyarakat dan respon kecewa masyarakat terhadap pelaku tindak pidana korupsi tersebut malah dijadikan sebagai alasan meringkan hukuman korban. Tidak ada nya upaya hakim dalam mewujudkan keadilan substantive dapat dilihat pula pada alasan meringankan yang terdapat pada putusan ini yang salah satu nya adalah yaitu bahwa terdakwa dinilai telah cukup menderita karean telah dicaci dan divonis oleh masyarakat padahal terdakwa belum tentu dinyatakan bersalah. Alasan meringankan tersebut dapat dibenarkan karena adanya Asas praduga tak bersalah. Asas praduga tak bersalah diatur dalam Penjelasan Umum KUHAP butir ke 3 huruf c yaitu:

"Setiap orang yang disangka, ditangkap, ditahan, dituntut dan atau dihadapkan di muka sidang pengadilan, wajib dianggap tidak bersalah sampai adanya putusan pengadilan yang menyatakan kesalahannya dan memperoleh kekuatan hukum tetap."

Sedangkan dalam Undang-Undang No. 48 Tahun 2009 tentang Kekuasaan Kehakiman Pasal 8 ayat (1) yaitu:

"Setiap orang yang disangka, ditangkap, ditahan, dituntut, atau dihadapkan di depan pengadilan wajib dianggap tidak bersalah sebelum ada putusan pengadilan yang menyatakan kesalahannya dan telah memperoleh kekuatan hukum tetap."

Namun apabila membahas putusan mengarah pada keadilan, secara otomatis putusan akan menjauh dari kepastian hukum. Untuk mewujudkan nya, maka hakim harus menghendaki proses penegakan hukum tidak sekedar menjalankan peraturan perundang-undangan, tetapi mengakomodir kehendak hukum masyarakat yang dikenal sebagai ide penegakan hukum progresif yang pro rakyat dan pro keadilan sebagaimana yang dicetuskan oleh Satjipto Rahardjo. Terlebih kasus korupsi dana bansos ini merugikan masyarakat dan beririsan dengan kerugian keuangan negara. Hakim Pegadilan Negeri Jakarta Pusat pada putusan nya kurang mempertimbangkan kerugian yang diterima masyarakat dan Negara, bahkan dalam hal penghitungan jumlah kerugian keuangan negara dari tindak pidana korupsi yang dilakukan JB pun dilakukan dengan langkah yang lamban padahal korupsi bansos ini sudah terbukti akan sangat berpengaruh pada kerugian keuangan negara jika berkaca pada praktik suap yang dilakuukan terdakwa mempengarhui secara langsung pada kualitas dan harga paket bansos itu sendiri. Bahkan, BPKP mengatakan potensi kerugian keuangan negara korupsi bansos ini dapat mencapai Rp2 triliun. Selanjutnya pada amar putusan, terdakwa dituntut untuk membayar uang pengganti sejumlah Rp14.597.450.000,00 (empat belas miliar lima ratus sembilan puluh tujuh juta empat ratus lima puluh ribu rupiah) dengan ketentuan apabila tidak dibayar paling lama 1 (satu) bulan setelah perkara ini mempunyai kekuatan hukum tetap, maka harta benda Terpidana dirampas untuk menutupi kerugian negara tersebut dan apabila harta bendanya tidak mencukupi untuk membayar uang pengganti maka diganti dengan pidana penjara selama 2 (dua) tahun.

\section{Kesimpulan}

Berdasarkan pembahasan dalam penelitian ini, peneliti menyimpulkan beberapa hasil penelitian 
sebagai berikut:

1. Hakim dalam menjatukah Putusan No.29/Pid-Sus/TPK/2021/ PN Jkt. Pst belum mengakomodir Pasal 52 KUHP sebagai unsur pemberat pidana terdakwa begitupun pada pertimbangan putusan nya hakim tidak menyertakan status terdakwa yang melakukan tindak pidana korupsi saat menjalankan kewenangan khusus dari jabatan umum nya yang mana hal tersebut telah memenuhi unsur yang ada pada Pasal 52 KUHP hal tersebut menyebabkan sanksi terlalu ringan bagi korupsi yang dilakukan oleh pejabat negeri dan dilakukan pada saat situaSi bencana nasional Pandemi COVID-19. Terdakwa jika dikenakan unsur pemberat Pasal 52 KUHP maka hukuman nya dapat diperberat sepertiga menjadi 16 tahun kurungan penjara.

2. Hakim dalam menjatuhkan Putusan No.29/Pid-Sus/TPK/2021/PN Jkt. Pst. belum memenuhi asas keadilan bagi masyarakat terutama yang menjadi korban dana bansos COVID-19 ini karena dalam pertimbangan nya Hakim tidak mengakomodir unsur kerugian yang diderita masyarakat dan respon kecewa masyarakat terhadap pelaku tindak pidana korupsi tersebut malah dijadikan sebagai alasan meringankan hukuman korban.

\section{Acknowledge}

Puji syukur penulis panjatkan kehadirat Allah SWT karena berkat Rahmat dan Karunia-Nya penulis dapat menyelesaikan penyusunan skripsi ini. Shalawat beserta salam semoga senantiasa terlimpah curahkan kepada Nabi Muhammad SAW, kepada keluarganya, para sahabatnya. Ucapa rasa syukur terima kasih dan rasa hormat penulis persempabhakan kepada pihak-pihak telah senantias membantu penulis dalam penelitian ini. Kepada kedua orang tua penulis, ibu Tita Rosita, Ayah Herrie Restoe, dan Bibi Wa Uti atas segala doa dan dukungan baik moral dan materil selama penelitian ini. Tak lupa penulis mengucapkan terimakasih kepada saudara saudaraku baik itu kakakku tercinta yaitu Elsa Emmanuelle, yang telah banyak memberikan dorongan, semangat, kasih sayang dan bantuan baik secara moril maupun materil demi lancarnya penyusunan skripsi ini, juga kedua adik yang penulis sayangi dan menjadi penyemangat hari harinya Shavira Putri Gabriella dan Rivaldy Oktavian, Dalam proses penyusunan skripsi ini, penulis tidak lepas dari berbagai kesulitan dan hambatan, akan tetapi berkat bantuan dan dorongan berbagai pihak maka skripsi ini dapat terselesaikan. Oleh karena itu, perkenankanlah penulis ucapkan terima kasih yang sebesar-besarnya kepada Bapak Dr. Ade Mahmud, S.H., M.H. selaku pembimbing penulisan hukum yang telah sabar untuk membimbing penulis dan memberikan arahan-arahan selama proses penulisan skripsi ini.

\section{Daftar Pustaka}

[1] Ade Mahmud. Pengembalian Aset Tindak Pidana Korupsi Pendekatan Hukum. 2020. Bandung: Sinar Grafika.

[2] Edi Setiadi dan Rena Yulia. Hukum Pidana Ekonomi. 2010. Yogyakarta: Graha Ilmu.

[3] Nandang Sambas dan Ade Mahmud Perkembangan Hukum Pidana dan Asas-Asas dalam RKUHP. 2019. Bandung: Refika Aditama.

[4] Alfitra. Hapusnya Hak Menuntut \& Menjalankan Pidana. 2012. Jakarta: Raih Asa Sukses

[5] Nandang Sambas dan Dian Andriasari. Kriminologi Perspektif Hukum Pidana. 2019. Bandung: Sinar Grafika.

[6] Soerjono Soekanto, Penelitian Hukum Normatif. 1998. Jakarta: Rajawali Press

[7] Evi Hartanti. Tindak Pidana Korupsi. 2005. Jakarta: Sinar Grafika

[8] Andi Hamzah. Sistem Pidana dan Pemidanaan Indonesia. 1993. Jakarta: PT. Pradnya Paramita

[9] Evi Oktarina dan Putri Sari Nilam Cayo, Pertanggungjawaban Hukum Pelaku Tindak Pidana Korupsi Bantuan Sosial, 2019, Prosiding Seminar Nasional Mewujudkan Masyarakat Madani dan Lestari, Jurnal Sekolah Tinggi Ilmu Hukum Sumpah Pemuda Volume 2 No. 24 Oktober 2019

[10] Oksidelfa Yanto. Penjatuhan Pidana Mati Pelaku Tindak Pidana Korupsi Dalam Keadaan 
Tertentu, Jurnal Legislasi Indonesia. 2017. Jurnal Fakultas Hukum Universitas Pamulang. Vol. 14 N0. 01 - Maret 2017

[11] Hendrika Beatrix Aprilia Ngape, Akibat Hukum Putusan Hakim Yang Menjatuhkan Putusan Diluar Surat Dakwaan Penuntut Umum, Justitia Jurnal Hukum, Fakultas Hukum Universitas Muhammadiyah Surabaya, Volume 2 No.1 April 2018

[12] Jesi Aryanto, Legitimasi Hukuman Mati di Indonesia dalam Kaitannya dengan Hak Hidup. Jurnal Hukum Adil, Fakultas Hukum Universitas Yarsi. Volume 2 No. 2 Agustus 2011 